\title{
PENGARUH SOCIAL MEDIA MARKETING DAN KUALITAS PELAYANAN TERHADAP KEPUTUSAN PEMBELIAN KPR NON SUBSIDI DENGAN MEDIASI PERSEPSI MEREK (STUDI PADA BANK XYZ)
}

\section{THE INFLUENCE OF SOCIAL MEDIA MARKETING AND SERVICE QUALITY ON PURCHASE DECISION OF NON-SUBSIDIZED MORTGAGE USING BRAND PERCEPTION AS A MEDIATING VARIABLE} (CASE STUDY OF BANK XYZ)

\author{
Santi Piramita*), Sufrin Hannan*), dan Jan Horas Vervady Purba**) \\ *) Sekolah Pascasarjana, Universitas Pakuan \\ Jl. Pakuan, Bogor 16129, Indonesia \\ **) Institut Bisnis dan Informatika Kesatuan \\ Jl. Suryakencana, Gg. Aut, Bogor 16131, Indonesia
}

\begin{abstract}
The purpose of this research is how to social media marketing and service quality to impact non-subsidized mortgage purchasing decisions, with brand perception as a mediating variable. The model in this research was designed using hierarchical components with a reflective-reflective measurement model consisting of four variables (social media marketing, service quality, brand perception and purchase decisions) and sixteen dimention (entertainment, informative, interactive, tangible, reliable, responsiveness, assurance, empathy, brand experience, brand affective, brand trust, recognition of needs, information search, evaluation of alternatives, purchase decisions and post-purchasing behavior). Data analysis in this research was using the Partial Least Square Structural Equation Modeling (PLS-SEM) method. The results revealed that social media marketing factors and service quality have a positive and significant effect on brand perception. In addition, social media marketing factors and brand perceptions were found to have a positive and significant effect on purchasing decisions and service quality factors which had an insignificant effect. The mediating role of brand perception was found to have a partial mediating effect on the relationship between social media marketing and purchasing decisions, while the relationship between service quality was found to be fully mediated.
\end{abstract}

Keywords: purchase decision, service quality, brand perception, social media marketing, non subsidized mortgage

\begin{abstract}
Abstrak: Penelitian ini bertujuan menganalisis pengaruh social media marketing dan kualitas pelayanan terhadap keputusan pembelian dengan persepsi merek sebagai variabel mediator pada salah satu Bank di Kota Bogor. Model dalam penelitian ini di design menggunakan hierarchical component dengan model pengukuran reflektif-reflektif yang terdiri empat variabel (social media marketing, service quality, persepsi merek dan keputusan pembelian) dan enam belas dimensi (entertainment, informative, interactive, tangible, reliable, responsiveness, assurance, emphaty, brand experience, brand affective, brand trust, pengenalan kebutuhan, pencarian informasi, evaluasi alternatif, keputusan pembelian dan perilaku pembelian). Analisis data dalam penelitian menggunakan metode Partial Least Square Structural Equation Modelling (PLS-SEM). Hasil dari penelitian ini menyatakan bahwa faktor social media marketing dan kualitas pelayanan berpengaruh positif dan signifikan terhadap persepsi merek. Selain itu, faktor social media marketing dan persepsi merek ditemukan berpengaruh positif dan signifikan terhadap keputusan pembelian. Namun, hasil yang berbeda ditunjukan oleh faktor kualitas pelayanan yang tidak berpengaruh signifikan. Peran mediasi dari persepsi merek ditemukan memiliki pengaruh mediasi parsial pada hubungan antara social media marketing terhadap keputusan pembelian sementara pada hubungan kualitas pelayanan ditemukan memediasi secara penuh.
\end{abstract}

Kata kunci: keputusan pembelian, kualitas pelayanan, persepsi merek, social media marketing, KPR non subsidi

\footnotetext{
${ }^{1}$ Corresponding author:

Email: santi.piramita@gmail.com
} 


\section{PENDAHULUAN}

Bank XYZ ditunjuk oleh pemerintah sebagai wadah pembiayaan perumahan rakyat pada tahun 1974 dengan memiliki misi melakukan tugas dan usaha dibidang perbankan dalam arti seluas-luasnya untuk menunjang pelaksanaan pembangunan nasional dalam rangka pemerataan pertumbuhan ekonomi kerakyatan dengan mengkhususkan diri pada proyek perumahan, hal tersebut sesuai dengan visi Bank XYZ untuk menjadi bank terdepan dan market leader dalam pembiayaan kredit perumahan. Bank XYZ untuk produk kredit pemilikan rumah/KPR menyalurkan 2 jenis kredit yaitu subsidi dan non subsidi. Untuk KPR subsidi Bank XYZ menjadi market leader dalam industri, namun untuk KPR non subsidi dari data yang diperoleh tahun 2015 hingga tahun 2019 realisasi KPR nya menempati peringkat kedua, telah disalip oleh bank swasta nasional. Selain itu pada tahun 2019 diketahui pula bahwa pertumbuhan KPR non subsidi Bank XYZ memiliki pertumbuhan terendah dibandingkan tahun 2018 diantara 6 bank dengan realisasi KPR tertinggi nasional. Berdasarkan data tersebut menjelaskan bahwa persaingan yang semakin banyak untuk produk KPR non subsidi di Indonesia bukan tidak mungkin dapat membuat pasar KPR non subsidi di bank XYZ semakin tergerus diambil dan didominasi oleh bank lain. Oleh karena itu, diperlukan penelitian lebih lanjut terkait hal apa saja yang dapat mempengaruhi peningkatan nasabah untuk dapat memutuskan membeli KPR non subsidi sehingga bank XYZ tetap menjadi market leader di bidang KPR secara keseluruhan.

Dapat diketahui bahwa salah satu permasalahannya yaitu strategi promosi pemasaran yang dilakukan oleh Bank XYZ masih belum optimal, Bank XYZ masih lebih fokus memasarkan produk KPR non subsidinya secara tradisional seperti radio, majalah, koran dan pameranpameran. Pada era 4.0 ini seperti saat ini, semua industri termasuk perbankan mengalami perubahan perilaku, dan aksesibilitas secara online merupakan suatu keharusan jika tidak ingin ditinggal oleh pasar. Hal tersebut dibuktikan dari data www.wearesocial.com per bulan januari 2020 sebesar 59\% penduduk dari Indonesia merupakan pengguna aktif di socialmedia. Di Bank $\mathrm{XYZ}$ pemasaran melalui social media masih belum optimal terbukti bahwa dibandingkan dengan 6 bank terbesar lainnya pengikut social media resmi Bank XYZ masih tertinggal. Bank BTN dapat memanfaatkan social media yang merupakan salah satu pasar sebagai tempat untuk mengoptimalkan promosi KPR Non subsidi sehingga dapat meningkatkan persepsi konsumen terhadap merek KPR non subsidi dan selanjutnya dapat memilih KPR Bank XYZ sebagai fasilitas pembiayaan perumahannya. Penerapan social media marketing yang optimal dapat menembus jangkauan yang lebih luas dan lebih cepat dikenal sehingga dapat menjadi pilihan di masyarakat.

Pada bank XYZ pelayanan KPR dijalankan oleh loan service. Penempatan loan service akan menciptakan kesan pertama yang baik atau buruk terhadap suatu merek produk bank. Faktanya pada saat ini loan service belum memiliki standarisasi penilaian kualitas dari pihak MRI dan kantor pusat seperti standarisasi front liner lainnya (customer service, teller service dan security). Jika kualitas pelayanan loan service tidak dijaga maka persepsi konsumen terhadap merek KPR non subsidi juga tidak baik dan memungkinkan konsumen akan beralih ke bank lain untuk memilih fasilitas KPR nya.

Brand KPR sejak lama melekat di Bank XYZ sebagai bank pertama penyedia fasilitas pembiayaan perumahan di Indonesia. Sesuai dengan survei yang dilakukan Frontier Research untuk TOP Brand Award periode tahun 2015-2020 terhadap merek produk KPR Bank, Bank XYZ menduduki peringkat pertama. Namun dapat diamati bahwa pertumbuhan pencapaian TOP Brand Index dari tahun 2015 - 2020 mengalami penurunan tergerus oleh bank lain. Sesuai dengan survei awal melalui wawancara yang dilakukan oleh peneliti bahwa 7 dari 10 orang menyatakan merek KPR masih melekat di Bank XYZ, namun bank pesaing juga mampu memberikan fasilitas dan harga yang lebih baik dari Bank XYZ jika Bank XYZ tidak lebih kompetitif bukan tidak mungkin konsumen akan berpaling ke bank lain. Dengan isu yang disampaikan di atas, perusahaan harus menciptakan merek produk yang berkualitas tinggi sehingga produknya bisa bersaing dengan kompetitor lainnya (Rismayadi et al. 2011).

Hudson et al. (2014) dalam penelitiannya menyimpulkan bahwa hubungan konsumen akan lebih tinggi jika melalui social media. Dari hal tersebut maka strategi peningkatan pemasaran melalui social media dapat meningkatkan persepsi terhadap sebuah merek akan semakin baik. Mengkonfirmasi penelitian dari Essays (2018) yang menemukan bahwa social media marketing berpengaruh positif dan signifikan terhadap persepsi merek. Terhadap keputusan pembelian Mileva dan Fauzi (2018) mengemukakan bahwa social media marketing berpengaruh positif terhadap keputusan pembelian dan 
social media marketing memiliki pengaruh yang lebih besar terhadap keputusan pembelian dibandingkan dengan traditional marketing (Tarabieh, 2017).

Najmahetal.(2019)dalampenelitiannyamengemukakan bahwa untuk meningkatkan persepsi pelanggan maka kualitas pelayanan harus dijaga. Sejalan dengan hal tersebut Adekunle dan Bello (2015) menyimpulkan bahwa kualitas pelayanan berpengaruh terhadap persepsi pelanggan. Dengan meningkatkan kualitas pelayanan yang semakin baik, maka persepsi pelanggan terhadap merek akan semakin baik. Terhadap keputusan pembelian Ratnasari (2014) menyatakan bahwa terdapat pengaruh positif dan signifikan kualitas pelayanan terhadap keputusan pembelian KPR. Ardiyanto (2010) dan Nugroho (2015) dalam penelitiannya menunjukkan bahwa persepsi merek memiliki pengaruh positif dan signifikan terhadap keputusan pembelian. Yang artinya dengan meningkatkan persepsi yang baik terhadap suatu merek maka keputusan pembelian juga akan meningkat. Oleh karena itu berdasarkan penelitian-penelitian sebelumnya dapat disimpulkan bahwa peningkatan social media marketing dan peningkatan kualitas pelayanan dapat meningkatkan persepsi merek yang nantinya akan menuntun pada keputusan pembelian konsumen.

Dalam penelitian ini memiliki kesamaan variabel yang diteliti secara parsial sehingga hasil penelitian ini dapat mendukung temuan yang sudah ada sebelumnya. Penelitian ini memiliki perbedaan dari segi objek dan model penelitian, alat analisis dan indikator-indikator yang digunakan untuk mengukur setiap variabel. Penelitian ini bertujuan untuk menganalisis pengaruh social media marketing dan kualitas pelayanan terhadap keputusan pembelian dengan persepsi merek sebagai variabel mediator pada salah satu Bank di Kota Bogor. Sehingga dapat memformulasikan implikasi manajerial dalam meningkatkan social media marketing, kualitas pelayanan, persepsi merek dalam peningkatan keputusan konsumen untuk memilih KPR non subsidi di Bank XYZ

\section{METODE PENELITIAN}

Penelitian dilaksanakan di Bank XYZ Kantor Cabang Bogor. Waktu penelitian dimulai dari bulan Februari sampai dengan Oktober 2020. Penelitian ini merupakan penelitian kuantitatif deskriptif yang menunjukkan pengaruh antar variabel dan mendeskripsikan serta menjelaskan keadaan dari objek penelitian pada saat melakukan penelitian. Sumber data yang digunakan yaitu data primer dan sekunder. Data primer yaitu berupa kuisioner yang di sebar secara online ataupun offline tergantung pada kesediaan responden. Data sekunder berupa sumber seperti studi jurnal atau sumber informasi online, serta laporan keuangan dan tahunan Bank XYZ yang terkait dengan penelitian.

Populasi dalam penelitian ini adalah debitur KPR non subsidi yang baru akad kredit lebih dari 3 bulan dan merupakan pengikut social media instagram Bank XYZ. Malhotra dan Dash (2016) dan Hair (2010) menyatakan apabila jumlah populasi tidak diketahui secara pasti maka jumlah sampel harus berukuran minimum lima kali dari jumlah indikator. Hair et al. (2005) menyatakan pedoman perhitungan kecukupan sampel pada penelitian ini adalah 5-10 kali parameter yang di estimasi Ukuran maksimum sebanyak 48 indikator dikalikan $10(48 \times 10=480$ sampel). Dari keseluruhan kuesioner yang disebarkan kepada 480 responden, hanya 320 dengan hit rate $(67 \%)$ yang memenuhi kriteria responden. Sehingga dalam penelitian ini yang diambil sebagai responden sebanyak 320 orang. Uji instrumen dilakukan sebelum penyebaran kuisioner terhadap 30 orang responden dengan menggunakan SPSS. Hasil uji menunjukkan bahwa setiap variabel yang digunakan reliable dan setiap indikator valid.

Variabel yang digunakan dalam penelitian ini adalah variabel eksogen $(\mathrm{X})$, variabel endogen $(\mathrm{Y})$ dan variabel mediasi. Pengukuran tiap instrument menggunakan ordinal skala Likert 1-7 dengan kriteria sangat setuju, setuju, agak setuju, ragu-ragu, agak tidak setuju, tidak setuju, sangat tidak setuju dengan definisi operasional sebagai berikut:

Variabel eksogen meliputi 1. Social media marketing merupakan bentuk pemasaran yang dilakukan oleh bank XYZ melalui socialmedia Instagram@BankXYZ untuk merek produk KPR non subsidi. Social media marketing memiliki dimensi (a) entertainment yang indikatornya terdiri menyenangkan, menarik, trendi (b) informative yang indikatornya terdiri dari kekinian, tulisan berkualitas, dan kustomisasi (c) interactive yang indikatornya terdiri dari membagikan, bertukar informasi, dan opini (Kim dan Ko, 2012), (Katiyar \& Saini,2016) dan (Andriani dan Putra, 2019). 2. Kualitas pelayanan yang merupakan kualitas pelayanan yang diterima oleh debitur untuk produk KPR non subsidi di Bank XYZ. Kualitas pelayanan memiliki dimensi 
(a) tangible dengan indikator penampilan fasilitas fisik, peralatan kantor, dan personil (b) reliability dengan indikator kredibilitas, tepat waktu, dan akurat (c) responsiveness dengan indikator etika karyawan, layanan prima, kesediaan membantu (d) assurance dengan indikator kesopanan, kepercayaan dan keyakinan (e) emphaty dengan indikator kepedulian, perhatian secara individu, dan memahami pelanggan (Alamgir dan Shamsudhoha, 2003) dan (Wibisono dan Widjaja, 2016).

Variabel endogen yaitu keputusan pembelian merupakan keputusan calon debitur dalam memilih KPR non subsidi di bank XYZ. Keputusan pembelian memiliki dimensi (a) pengenalan kebutuhan dengan indikator keinginan, kebutuhan dan stimulan. (b) pencarian informasi dengan indikator sumber pribadi, sumber komersial dan sumber umum (c) evaluasi alternatif dengan indikator perbandingan merek lain, standarisasi kualitas, dan pilihan produk (d) keputusan pembelian dengan indikator kemantapan membeli, sesuai dengan kebutuhan, dan fasilitas pembayaran mudah (e) perilaku pasca pembelian dengan indikator kepuasan, membeli kembali, dan merekomendasikan (Kottler dan Keller, 2009).

Variabel mediasi dalam penelitian ini adalah persepsi merek yang merupakan persepsi terhadap merek KPR non subsidi di Bank XYZ. Persepsi merek memiliki 3 dimensi yaitu (a) brand experience dengan indikator pengalaman baik, pengalaman puas dan membangkitkan rasa sentimen (b) brand affect dengan indikator merek diinginkan, merek disukai, merek membuat bahagia (c) brand trust dengan indikator yakin baik, yakin hemat, yakin aman (Christodoulides, 2006; Aslam dan Farhat, 2018). Persepsi merek pada penelitian ini juga sebagai variabel endogen untuk diukur apakah dipengaruhi oleh social media marketing dan kualitas pelayanan serta sebagai variabel eksogen untuk diuji apakah mempengaruhi keputusan pembelian.

Alat analisis dalam penelitian ini menggunakan statistic deskriptif dan Structural Equational Modelling Partial Least Square (SEM-PLS) dengan menggunakan program Smart PLS versi 3.2.8. SEM PLS digunakan untuk mengetahui pengaruh antar variabel. Kriteria yang digunakan dalam SEM-PLS meliputi uji model pengkuran (outer model), uji model struktural (inner model) dan evaluasi model mediasi. Uji model pengukuran (outer model) dinilai melalui uji reliabilitas dan validitas. Pengujian validitas dan reliabilitas konstruk dengan indikator refleksif dengan ringkasan pada Tabel 1 .

Model struktural (inner model) berfungsi untuk memprediksi hubungan sebab akibat antar variabel yang dievaluasi menggunakan $R$-Square $\left(\mathrm{R}^{2}\right)$, path coefficient, $T$ statistic dan evaluasi model fit.. R Square mengukur seberapa besar pengaruh variabel endogen dapat dijelaskan oleh eksogennya. Analisis pada path coefficient menurut Helm et al. (2009) dalam Hair et al. (2014) menjelaskan bahwa nilai koefisien jalur yang mendekati +1 merepresentasikan hubungan positif yang kuat dan nilai koefisien jalur yang -1 mengindikasikan hubungan negatif yang kuat serta dapat menyusun model struktural (Nurwulan et al. 2015). Pengujian t statistic dilakukan untuk pengujian hipotesis terkait tingkat signifikansi dengan membandingkan nilai $\mathrm{t}$ hitung terhadap $\mathrm{t}$ tabel pada tingkat signifikansi alpha $5 \%$. Jika nilai $\mathrm{t}$ hitung $>\mathrm{t}$ tabel $(1,96)$, maka hipotesis diterima. Sebaliknya jika nilai $\mathrm{t}$ hitung $<\mathrm{t}$ tabel $(1,96)$, maka hipotesis tersebut ditolak. Evaluasi model fit menggunakan Standardized Root Mean Square Residual (SRMR), model akan dipertimbangkan memiliki good fit jika nilai (SRMR) dibawah 0,08 (Hair et al. 2014).

Tabel 1. Rule of thumb model pengukuran

\begin{tabular}{lll}
\hline Validitas dan Reliabilitas & Parameter & Rule of Thumb \\
\hline Validitas Convergent & Loading Factor & $>0,60$ untuk Exploratory Research \\
& $\begin{array}{l}\text { Average Variance } \\
\text { Extracted (AVE) }\end{array}$ & $>0,50$ untuk Confirmatory maupun Exploratory Research \\
Validitas Discriminant & Cross Loading & $>0,70$ untuk setiap variabel \\
& HTMT Inference & Confidence Interval $<1$ \\
Reliabilitas & $>0,70$ untuk Confirmatory Research \\
& & $>0,60$ masih dapat diterima untuk Exploratory Research \\
& Composite Reliability & $>0,70$ untuk Confirmatory Research \\
& & $0,60-0,70$ masih dapat diterima untuk Exploratory Research \\
\hline
\end{tabular}


Evaluasi model mediasi dalam penelitian ini untuk menguji apakah persepsi merek sebagai variabel mediasi memiliki efek mediasi secara partial, penuh ataupun tidak memiliki pengaruh terhadap hubungan variabel eksogen terhadap endogen. Pada penelitian ini menggunakan design hierarchical component dengan model pengukuran reflektif-reflektif yang terdiri dari empat konstruk higher-order component (HOC) sebagai variabel dan enam belas konstruk lower-order component (LOC) sebagai dimensi yang digambarkan pada konstelasi penelitian. Harapannya hasil penelitian ini dapat memberikan kontribusi bagi Bank XYZ untuk dapat menentukan langkah alternatif kebijakan yang dapat meningkatkan keputusan konsumen untuk lebih memilih KPR non subsidi di Bank XYZ dari faktorfaktor yang diteliti dibandingkan bank lain. Sehingga kerangka pemikiran penelitian dapat disajikan pada Gambar 1.

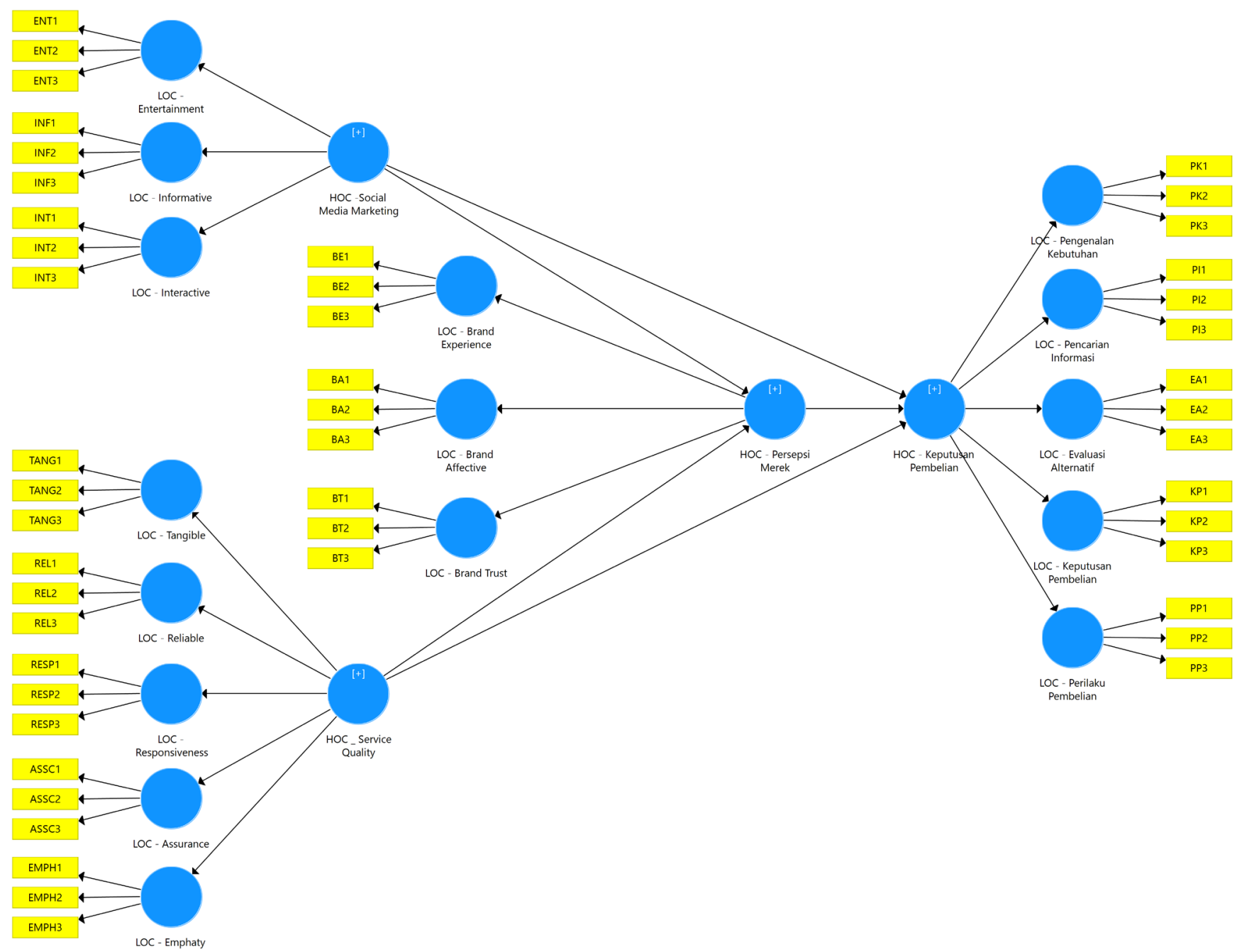

Keterangan:

Endogonous : KP (Keputusan Pembelian)

Exsogeneous : SMM (Social Media Marketing), Servqual (Kualitas Pelayanan)

Mediator : PM (Persepsi Merek)

Lower Order Component (LOC): ENT (Entertainment), INF (Informative), INT (Interactive), TANG (Tangibility), RELI (Reliability), RESP (Responsiveness), ASSC (Assurance), EMPH (Emphaty), BE (Brand Experience), BA (Brand Affective), BT (Brand Trust), PK (Pengenalan Kebutuhan), PI (Pencarian Informasi), EA (Evaluasi Alternatif), KP (Keputusan Pembelian), PP (Perilaku Pasca Pembelian)

Gambar 1. Kerangka pemikiran penelitian 
Penerapan social media marketing dan kualitas pelayanan yang semakin baik akan meningkatkan persepsi terhadap sebuah merek. Persepsi merek juga memiliki kaitan erat dengan keputusan pembelian sehingga diharapkan semakin baik persepsi merek maka akan meningkatkan konsumen untuk memilih KPR non subsidi di Bank XYZ. Selain itu dengan usaha meningkatkan persepsi merek yang baik di benak masyarakat maka akan meningkatkan hubungan antara social media marketing dan kualitas pelayanan dalam meningkatkan keputusan pembelian KPR non subsidi di Bank XYZ. Berdasarkan latar belakang, penelitian terdahulu dan kerangka pemikiran pada penelitian ini maka disusun hipotesis penelitian sebagai berikut:

$\mathrm{H}_{1}$ : Social media marketing berpengaruh positif dan signifikan terhadap persepsi merek

$\mathrm{H}_{2}$ : Kualitas pelayanan berpengaruh positif dan signifikan terhadap persepsi merek

$\mathrm{H}_{3}$ : Social media marketing berpengaruh positif dan signifikan terhadap keputusan pembelian

$\mathrm{H}_{4}$ : Kualitas pelayanan berpengaruh positif dan signifikan terhadap keputusan pembelian

$\mathrm{H}_{5}$ : Persepsi merek berpengaruh positif terhadap keputusan pembelian

$\mathrm{H}_{6}$ : Persepsi merek memediasi hubungan social media marketing terhadap keputusan pembelian

$\mathrm{H}_{7}$ : Persepsi merek memediasi hubungan kualitas pelayanan terhadap keputusan pembelian

\section{HASIL}

Dari hasil uji model pengukuran (outer model) diketahui bahwa indikator dan dimensi telah memenuhi rule of thumb dengan nilai loading factor diatas 0.6 sehingga indikator dan dimensi valid dan dapat mengukur serta mengkonfirmasi konstruk/ variabel. Selain itu ditemukan bahwa nilai confidence interval (CI) dari setiap indikator terhadap dimensi dan variabel nilainya kurang dari atau sama dengan 1,00 Sehingga disimpulkan setiap indikator pendukung tidak terdapat permasalahan discriminant validity. Hasil uji reliabilitas diketahui bahwa nilai cronbach's alpha dan composite reliability dari semua variabel diatas 0,7 dan begitu pula dengan nilai average variance extracted diatas 0,5 sehingga memenuhi persyaratan reliabilitas.

Pada penelitian untuk hasil uji model struktural (inner model), nilai $\mathrm{R}$-Square $\left(\mathrm{R}^{2}\right)$ atau koefisien determinasi dari konstruk persepsi merek sebesar 0,802 artinya variabel endogen persepsi merek dapat dijelaskan oleh variabel eksogen yaitu social media marketing dan kualitas pelayanan sebesar $80 \%$ sedangkan sisanya sebanyak $20 \%$ dijelaskan oleh variabel eksogen lainnya diluar penelitian ini. Variabel endogen kedua dari konstruk yaitu keputusan pembelian ditemukan nilai R-Square $\left(\mathrm{R}^{2}\right)$ sebesar 0,718 artinya keputusan pembelian dapat dijelaskan oleh variabel eksogen yaitu social media marketing, kualitas pelayanan dan persepsi merek sebesar $72 \%$ sedangkan sisanya sebanyak $28 \%$ dijelaskan oleh variabel eksogen lainnya diluar penelitian ini. Nilai SRMR pada penelitian ini sebesar $0,082<0,1$, hal ini menunjukkan bahwa model dalam penelitian ini memiliki good fit. Untuk hasil pengujian hipotesis dijelaskan pada Tabel 2.

\section{Hubungan antara Social Media Marketing terhadap Persepsi Merek}

Berdasarkan hasil pengujian pada Tabel 2 dapat disampaikan bahwa hubungan antara social media marketing terhadap persepsi merek memiliki nilai (path coefficients) 0.407 mendekati nilai +1 sehingga merepresentasikan hubungan positif. Nilai T-Statistic $6,904(>1,96)$ menunjukkan bahwa social media marketing mempengaruhi secara siginifikan terhadap persepsi merek. Sehingga dapat disusun persamaan struktural sebagai berikut:

$$
\eta_{1}=0,407 \quad \xi_{1}
$$

Keterangan: $\xi_{1}($ Ksi, variabel laten eksogen social media marketing); $\eta_{1}$ (Eta, variabel laten endogen persepsi merek)

Dari persamaan dapat disimpulkan bahwa hipotesis pertama (H1) diterima, yaitu social media marketing berpengaruh positif dan signifikan terhadap persepsi merek sesuai penelitian Essays (2018) dan Hudson et al. (2014). Pengujian untuk mengetahui pengaruh social media marketing terhadap konstruk dimensi persepsi merek ditemukan bahwa social media marketing memiliki pengaruh positif dan signifikan yang paling tinggi terhadap konstruk dimensi brand affective $(\beta=0,356, t=6,641, p=0,000)$. Hal tersebut dapat memberikan informasi bahwa Bank XYZ dapat mengoptimalkan promosi produk KPR XYZ non subsidi melalui social media instagram yang berisikan konten yang menyentuh emosi dan perasaan terbukti dapat meningkatkan persepsi merek yang lebih baik. 
Tabel 2. Hasil pengujian hipotesis

\begin{tabular}{lccl}
\hline Hipotesis & Path Coefficient & T-Statistics & Hasil \\
\hline H1 & 0,407 & 6,904 & Positif dan Signifikan \\
H2 & 0,527 & 9,500 & Positif dan Signifikan \\
H3 & 0,184 & 2,004 & Positif dan Signifikan \\
H4 & 0,141 & 1,476 & Positif dan Tidak Signifikan \\
H5 & 0,557 & 6,305 & Positif dan Signifikan \\
H6 & 0,227 & 4,927 & Positif dan Signifikan \\
H7 & 0,293 & 4,994 & Positif dan Signifikan \\
\hline
\end{tabular}

\section{Hubungan antara Kualitas Pelayanan terhadap Persepsi Merek}

Berdasarkan hasil olahan pada Tabel 2, hubungan antara kualitas pelayanan terhadap persepsi merek ditemukan memiliki nilai path coefficient 0,527 yang mendekati nilai +1 yang merepresentasikan hubungan positif yang kuat. Nilai T-Statistic 9,500 (>1,96) menunjukkan kualitas pelayanan berpengaruh signifikan terhadap persepsi merek. Sehingga dapat disusun persamaan struktural sebagai berikut:

$$
\eta_{1}=0,527 \xi_{2}
$$

Keterangan: $\xi_{2}$ (Ksi, variabel laten eksogen kualitas pelayanan); $\eta_{1}$ (Eta, variabel laten endogen persepsi merek)

Dari persamaan diatas dapat disimpulkan bahwa hipotesis kedua $(\mathrm{H} 2)$ diterima yaitu kualitas pelayanan berpengaruh positif dan signifikan terhadap persepsi merek sekaligus mengkonfirmasi penelitian Hossain dan Leo (2009) dan Najmah et al. (2020). Pengujian hipotesis untuk mengetahui pengaruh kualitas pelayanan terhadap konstruk dimensi persepsi merek. Ditemukan bahwa kualitas pelayanan memiliki pengaruh positif dan signifikan paling tinggi terhadap konstruk dimensi brand trust $(\beta=0,476, \mathrm{t}=9,652, \mathrm{p}=0,000)$. Sehingga dapat disimpulkan bahwa dengan meningkatkan kualitas layanan yang diberikan oleh petugas loan service di Bank XYZ maka dapat meningkatkan persepsi atas merek produk KPR non subsidi untuk bisa lebih dapat dipercaya oleh konsumen.

\section{Hubungan Antara Social Media Marketing Terhadap Keputusan Pembelian}

Berdasarkan hasil pengujian pada Tabel 2 hubungan antara social media marketing terhadap keputusan pembelian ditemukan memiliki nilai path coefficient 0.184 yang mendekati nilai +1 yang merepresentasikan hubungan yang positif. Nilai T-Statistic 2,004 $(>1,96)$ menunjukkan bahwa social media marketing memiliki pengaruh signifikan terhadap keputusan pembelian. Sehingga dapat disusun persamaan struktural sebagai berikut:

$$
\eta_{2}=0,184 \xi_{1}
$$

Keterangan: $\xi_{1}$ (Ksi, variabel laten eksogen social media marketing); $\eta_{2}$ (Eta, variabel laten endogen keputusan pembelian)

Dari persamaan diatas dapat disimpulkan bahwa hipotesis ketiga (H3) diterima yaitu social media marketing berpengaruh positif dan signifikan terhadap keputusan pembelian sesuai penelitian Ramsunder (2011) \& Hardey, (2011). Hipotesis untuk mengetahui pengaruh social media marketing terhadap konstruk dimensi keputusan pembelian menunjukkan bahwa social media marketing memiliki pengaruh positif dan signifikan yang paling tinggi terhadap konstruk dimensi evaluasi alternatif $(\beta$ $=0,168, \mathrm{t}=2,002, \mathrm{p}=0,045)$. Dapat disimpulkan Bank XYZ dapat memaksimalkan penggunaan social media instagram yang memuat konten yang berisikan semua informasi yang dibutuhkan oleh pelanggan sehingga proses evaluasi alternatif dari pelanggan berjalan lancar untuk mereka dapat segera memutuskan membeli KPR non subsidi di Bank XYZ.

\section{Hubungan Antara Kualitas Pelayanan Terhadap Keputusan Pembelian}

Berdasarkan hasil olahan peneliti pada Tabel 2, hubungan antara kualitas pelayanan terhadap keputusan pembelian ditemukan memiliki nilai path coefficients 0,141 yang mendekati nilai +1 namun memiliki nilai T-Statistic 1.476 $(<1,96)$. Sehingga dapat disimpulkan bahwa hipotesis keempat (H4) ditolak dan kualitas pelayanan tidak berpengaruh signifikan terhadap keputusan pembelian sesuai penelitian Ena, Nyoko dan Ndoen (2019). Untuk produk KPR non subsidi di Bank XYZ, kualitas 
pelayanan bukan merupakan faktor utama dalam mempengaruhi konsumen dalam pembelian produk. Berdasarkan teori yang dikemukan oleh Brady dan Cronin (2001), kualitas pelayanan merupakan tahapan layanan yang disediakan untuk menemukan kebutuhan dan kelemahan sehingga baru dapat meningkatkan persepsi konsumen atas penawaran layanan berkualitas tinggi, namun tidak dapat secara langsung memberikan pengaruh terhadap keputusan pembelian untuk sebuah produk.

\section{Hubungan antara Persepsi Merek dan Keputusan Pembelian}

Berdasarkan hasil olahan peneliti pada Tabel 2 hubungan antara persepsi merek terhadap keputusan pembelian ditemukan memiliki nilai path coefficient 0,557 yang mendekati nilai +1 yang merepresentasikan hubungan yang positif. Nilai T-Statistic 6,305 $(>1,96)$ menunjukkan bahwa persepsi merek berpengaruh signifikan terhadap keputusan pembelian. Sehingga dapat disusun persamaan struktural sebagai berikut:

$$
\eta_{2}=0,557 \xi_{3}
$$

Keterangan: $\xi_{3}$ (Ksi, variabel laten eksogen persepsi merek); $\eta_{2}$ (Eta, variabel laten endogen keputusan pembelian).

Dari persamaan dapat disimpulkan bahwa hipotesis kelima (H5) diterima dan persepsi merek berpengaruh positif dan signifikan terhadap keputusan pembelian mengkonfirmasi penelitian dari Wahyuni, (2008), Ardiyanto (2010), Sadeghi et al. (2011) dan Pebriani (2016). Pengujian hipotesis untuk mengetahui pengaruh persepsi merek terhadap konstruk dimensi keputusan pembelian menunjukkan bahwa persepsi merek memiliki pengaruh positif dan signifikan yang paling tinggi terhadap konstruk dimensi keputusan pembelian $(\beta=0,517, \mathrm{t}=6,263, \mathrm{p}=0,000)$. Bank XYZ harus berupaya untuk dapat menjaga dan meningkatkan persepsi atas merek KPR non subsidi tetap baik agar dapat meningkatkan konsumen untuk membeli produk KPR tersebut.

\section{Hubungan Antara Social Media Marketing Terhadap Keputusan Pembelian Melalui Persepsi Merek}

Hasil pengujian pada Tabel 2 menunjukkan nilai path coefficient 0.227 yang mendekati +1 yang artinya terdapat hubungan yang positif antara social media marketing terhadap keputusan pembelian melalui persepsi merek. Nilai T-Statistic 4,927 (>1,96) menunjukkan bahwa social media marketing memiliki pengaruh yang siginifikan terhadap keputusan pembelian melalui persepsi merek. Sehingga dapat disusun persamaan struktural sebagai berikut:

$$
\eta_{2}=0,227 \eta_{1}+0,184 \xi_{1}
$$

Keterangan: $\eta_{2}$ (Eta, variabel laten endogen keputusan pembelian); $\eta_{1}$ (Eta, variabel laten endogen persepsi merek); $\xi_{1}$ (Ksi, variabel laten eksogen social media marketing).

Dari persamaan dapat disimpulkan bahwa hipotesis keenam (H6) diterima bahwa persepsi merek memediasi hubungan antara social media marketing terhadap keputusan pembelian. Persepsi merek memediasi hubungan secara parsial (partial mediation) antara social media marketing terhadap keputusan pembelian, hal tersebut dikarenakan jika sebelumnya diketahui social media marketing terhadap keputusan pembelian memiliki pengaruh positif dan signifikan, pengaruh tersebut juga ditemukan jika melalui persepsi merek. Sehingga ada atau tidaknya persepsi merek, social media marketing dapat mempengaruhi keputusan pembelian. Namun pemasaran produk KPR non subsidi melalui social media instagram akan lebih efektif mendorong konsumen untuk membeli produk jika persepsi konsumen atas merek produk sudah tercipta baik

\section{Hubungan Antara Kualitas Pelayanan Terhadap Keputusan Pembelian Melalui Persepsi Merek}

Berdasarkan hasil olahan peneliti pada Tabel 2 hasil pengujian pada pengaruh tidak langsung dari kualitas pelayanan terhadap keputusan pembelian melalui variabel mediasi persepsi merek memiliki path coefficient 0,293 yang mendekati +1 yang merepresentasikan hubungan yang positif. Nilai T-Statistic 4,994 (>1,96) menunjukkan kualitas pelayanan memiliki pengaruh yang signifikan terhadap keputusan pembelian melalui persepsi merek. Sehingga dapat disusun persamaan struktural sebagai berikut:

$$
\eta_{2}=0,293 \eta_{1}+0,141 \xi_{2}
$$

Keterangan: $\eta_{2}$ (Eta, variabel laten endogen keputusan pembelian); $\eta_{1}$ (Eta, variabel laten endogen persepsi merek); $\xi_{2}$ (Ksi, variabel laten eksogen kualitas pelayanan). 
Dari persamaan dapat disimpulkan bahwa hipotesis ketujuh (H7) diterima, persepsi merek memediasi hubungan antara kualitas pelayanan terhadap keputusan pembelian. Persepsi merek memediasi hubungan secara penuh (full mediation) antara kualitas pelayanan terhadap keputusan pembelian, hal tersebut dikarenakan adanya perubahan yang terjadi pada pengaruh hubungan jika melalui persepsi merek. Jika sebelumnya diketahui kualitas pelayanan terhadap keputusan pembelian memiliki pengaruh yang tidak signifikan, pengaruh tersebut berubah jika melalui persepsi merek, kualitas pelayanan terhadap keputusan pembelian memiliki pengaruh positif dan signifikan. Dapat disimpulkan bahwa upaya meningkatkan persepsi merek KPR non subsidi di Bank XYZ merupakan hal yang sangat penting untuk dapat mendorong kualitas pelayanan dari loan service dapat mempengaruhi konsumen untuk membeli produk KPR non subsidi. Konsumen hanya akan menilai kualitas layanan loan service itu baik dan memutuskan membeli produk Bank XYZ jika persepsi merek telah terbentuk pada dirinya.

\section{Implikasi Manajerial}

Pentingnya membangun dan meningkatkan persepsi masyarakat yang baik terhadap merek KPR non subsidi di Bank XYZ. Hal ini dikarenakan dengan persepsi yang telah melekat di benak konsumen akan memudahkan konsumen memilih KPR di Bank XYZ dibandingkan bank lain dan memudahkan perusahaan dalam memasarkan produknya melalui social media melalui ulasan-ulasan baik yang diterima konsumen setelah menggunakan merek produk KPR mereka (brand experience). Pengawasan oleh supervisor dan manager secara ketat terhadap kualitas pelayanan yang diberikan loan service agar dapat lebih responsif dalam melayani konsumen dan konsisten dalam memberikan layanan prima. Dengan kualitas pelayanan yang terjaga maka persepsi konsumen akan semakin baik sehingga konsumen tidak ragu untuk memilih produk KPR non subsidi di Bank XYZ.

\section{KESIMPULAN DAN SARAN}

\section{Kesimpulan}

Social media marketing berpengaruh positif dan signifikan terhadap persepsi merek, kualitas pelayanan berpengaruh positif dan signifikan terhadap persepsi merek. Selain itu social media marketing berpengaruh positif dan signifikan terhadap keputusan pembelian, kualitas pelayanan tidak berpengaruh signifikan terhadap keputusan pembelian, persepsi merek berpengaruh positif dan signifikan terhadap keputusan pembelian. Sementara pada peran mediasi ditemukan bahwa persepsi merek memediasi hubungan antara social media marketing terhadap keputusan pembelian dan juga memediasi hubungan antara kualitas pelayanan terhadap keputusan pembelian.

\section{Saran}

Pihak manajemen perusahaan diera 4.0 saat ini dapat fokus memasarkan produknya melalui social media dengan memberikan konten yang menarik dan berisikan informasi pentingnya membeli rumah sebagai kebutuhan pokok yang dapat dimiliki melalui KPR Bank XYZ. Saran untuk penelitian selanjutnya yaitu mengukur kembali variabel social media marketing untuk melihat perbedaan hasil penelitian dengan studi kasus yang berbeda, mengingat variabel tersebut ditemukan memiliki nilai pengaruh terendah diantara faktor lainnya. Melibatkan responden dari berbagai domisili maupun kategorisasi lainnya secara lebih proporsional untuk dapat meningkatkan generalisasi dari hasil penelitian. Melakukan perbandingan analisis dengan menggunakan beberapa klasifikasi perbedaan wilayah domisili, karakteristik generasi dan lain sebagainya. Hal ini diharapkan dapat menambah referensi untuk pengambilan keputusan terkait strategi pemasaran.

\section{DAFTAR PUSTAKA}

Alamgir M, Shamsuddoha M. 2003. Service quality dimension: a conceptual analysis. The Chittagong University Journal of Business Administration 19:1-11.

Andriani R, Putra WBTS. 2019. The intersection of marketing and human resources dicipline: employer brand equity as a mediator in recruitment process. International Journal of Innovative Science and Research Technology (4): 465-475.

Ardiyanto A. 2010. Pengaruh Persepsi Merek dan Aktivitas terhadap Keputusan Pembelian. [Skripsi]. Surakarta: FISIP Universitas Sebelas Maret Surakarta.

AslamW, Ham M, Farhat K.2018. Influencing factors of brand perception on consumers repurchase 
intention: an examination of online apparel shopping. Journal of Contemporary Management Issue Management 23 (2):87-101.

Brady, Michael, Cronin Jr J. 2001. Some new thoughts on conceptualizing perceived service quality: a hierarchical approach. Journal of Marketing - $J$ MARKETING 65:34-49.

Christodoulides G, De Chernatony L, Furrer O, Shiu E, Abimbola T. 2006. Conceptualizing and measuring the equity of online brands. Journal of Marketing Management 22:799-825.

Chin WW. 1998. The Partial Least Square Approach For Structural Equation Modelling. In G.A. Marcoulides (Ed), Modern Methodes For Business Research. London: Lawrence Erlbaum Associates.

Chin WW. 2010b. How to write up and report PLS analysis. In V.E. Vinzi. W.W. Chin, J. Henseler \& H.Wang (Eds), Handbook of partial least square: Concept, methodes and application in marketing and related fields.

Ena MY, Nyoko AEL, Ndoen WM. 2019. Pengaruh persepsi harga, kualitas pelayanan, lokasi dan word of mouth terhadap keputusan pembelian di Chezz Cafenet. Journal of Management (SME's) 10(3): 299-310

Essays UK. 2018. An Investigation into the Impact of Social media on Brand Perception. Retrieved from https://www.ukdiss.com/examples/socialmedia-brand-perception.php? vref $=1$

Ghozali I, Latan H. 2015. Partial Least Square Konsep Teknik dan Aplikasi Menggunakan Program SmartPLS 3.0 (edisi kedua). Semarang: Badan Penerbit Universitas Diponegoro.

Hair JF, Ringle CM, Sarstedt M. 2011. PLS-SEM: indeed a silver bullet. Journal of Marketing Theory and Practice 19(2): 139-151.

Hair JF, Sarstedt M, Ringle CM, Mena JA. 2012. An Assesment of theuse of partial least square structural equation modelling in marketing research. Journal of the Academy of Marketing Science 40 (1): 414-433.

Hair JF, Sarstedt M, Hopkins L, Kuppelwieser VG. 2014. Partial least squares structural equation modeling (PLS-SEM): An emerging tool in business research. European Business Review 26(2): 106-121. http://doi.org/10.1108/EBR-102013-0128

Hardey M. 2011. Generations content creations, connections, and choice. International Journal of Market Research 53 (6): 749-770.
Helal G, Ozuem W, Lancaster G. 2018. Social media brand perceptions of millennials. International Journal of Retail \& Distribution Management 46 (10):977-998.

Hossain M, Leo S. 2009. Customer perception on service quality in retail banking in middle east: the case of Qatar. International Journal of Islamic and Middle Eastern Finance and Management 2 (4): 338-350.

Hudson S, Huang L, Roth, Madden T. 2014. The influence of social media interactions on consumer-brand relationships: A three-country study of brand perceptions and marketing behaviors. International Journal of Research in Marketing 33(1):27-41.

Katiyar V, Saini G K. 2015. Impact of organizational social media activities on employer brand equity and prospective applicants intentions to apply. NMIMS Management Review XXVIII:11-31.

KimA, Ko E. 2012. Do social media marketing activities enhance customer equity? An empirical study of luxury fashion brand. Journal of Business Research 65:1480-1486.

Kotler P, Keller KL. 2009. Manajemen Pemasaran Jilid 1. Edisi 13. Jakarta: Erlangga.

Mileva L, Fauzi D H. 2018. Pengaruh social media marketing terhadap keputusan pembelian. Jurnal Administrasi Bisnis (JAB) 58(1):190-199.

Nugroho RR. 2015. Pengaruh Persepsi Merek dan Kualitas Produk terhadap Keputusan Pembelian Smartphone [Skripsi]. Surabaya: Fakultas Ekonomi dan Bisnis Universitas Brawijaya.

Nurwulan E, Suharno, Nitaprilla N. 2015. Aplikasi partial least square dalam pengujian implikasi jaringan kerjasama dan inovasi usaha mikro kecil pengolahan kedelai. Informatika Pertanian 24(2): 205 - 214.

Ramsunder M. 2011. The Impact of Social Media Marketing on Purchase Decision in Tyre Industry [Tesis]. Faculty of Business and Economic Sciences At the Nelson Mandela Metropolitan University Business School.

Ratnasari F. 2014. Analisis faktor-faktor yang mempengaruhi keputusan nasabah dalam mengambil kredit [Skripsi]. Surakarta: Fakultas Ekonomi dan Bisnis Universitas Muhamadiyah Surakarta.

Rismayadi B, Isyanto P, Noviani AD.2011. Analisis persepsi merek terhadap perilaku konsumen produk indosat. Solusi 9(19): 53-65.

Sadeghi H, Khazaei F, Yari, Sheidaei S. 2011. Effect of 
seed osmopriming on seed germination behavior and vigor of soybean (Glycine max L.). ARPN Journal of Agricultural and Biological Science 6(1): 39-43.

Tarabieh SMZA. 2017. The synergetic impact of social media and traditional media on purchase decision: the mediating role of brand loyalty. International Review of Management and Marketing 7(5): 5162.
Wahyuni DU. 2008. Pengaruh motivasi, persepsi dan sikap konsumen terhadap keputusan pembelian sepeda motor merek "Honda" di Kawasan Surabaya Barat. Jurnal Manajemen Dan Kewirausahaan 10(1): 30-37.

Wibisono O, Deborah W. 2017. Analisa pengaruh kualitas produk dan kualitas layanan terhadap kepuasan pelanggan dan loyalitas pelanggan di Pisa Kafe Surabaya. Jurnal Hospitality dan Manajemen Jasa 5(1): 60-70. 